\title{
Polymorphism Report
}

\section{C306A single nucleotide polymorphism in the human CEBPD gene that maps at 8p11.1-p11.2}

\author{
Debora Angeloni, ${ }^{1 *}$ Joshua D. Lee, ${ }^{1}$ Bruce E. Johnson, ${ }^{2}$ Bin Tean Teh, ${ }^{3}$ \\ Michael Dean, ${ }^{4}$ Michael I. Lerman ${ }^{1}$ and Esta Sterneck ${ }^{5}$
}

${ }^{1}$ Laboratory of Immunobiology, National Cancer Institute at Frederick, Frederick, MD 21702, USA, ${ }^{2}$ Dana-Farber Cancer Institute, Boston, MA 02115, USA, ${ }^{3}$ Van Andel Research Institute, Gran Rapids, MI 49503, USA, ${ }^{4}$ Laboratory of Genomic Diversity, National Cancer Institute at Frederick, Frederick, MD 21702, USA and ${ }^{5}$ Regulation of Cell Growth Laboratory, National Cancer Institute at Frederick, Frederick, MD 21702, USA

(Received 20 October 2000, Accepted 2 July 2001)

KEYWORDS: CEBPD, single nucleotide polymorphism (SNP).

\section{INTRODUCTION}

The CCAAT/enhancer binding protein delta (CEBPD, GenBank accession number NM_005195, OMIM entry number 116898) is a member of the CEBP family of the basic-leucine zipper class of transcriptional regulators. While low levels of CEBPD mRNA are detectable in several organs of adult mice and humans, expression is dramatically induced by bacterial lipopolysaccharide and inflammatory cytokines, suggesting a role in the acute phase and inflammatory responses. ${ }^{1}$ In the lung, however, CEBPD is constitutively expressed. In rabbit fetal lung, expression increases to adult levels by late gestation. CEBPD expression is also activated during differentiation of human fetal lung tissue in culture. ${ }^{2}$ A number of differentiation specific genes are implicated as targets for CEBP regulation, e.g. Clara cell secretory protein, surfactant protein and annexin I. ${ }^{3,4,5}$ By immunostaining, the CEBPD protein was localized to rat alveolar type II cells ${ }^{6}$ and bronchiolar Clara cells. ${ }^{7}$ These cell types are the primary origin of pulmonary adenocarcinoma. $^{8}$ Therefore, to investigate the possible role of the CEBPD gene in causing lung cancer, we have done mutation analysis of the gene, with the single-strand conformational polymorphism (SSCP) method, on a collection of normal/tumour-paired DNA samples obtained from non-small-cell lung cancer patients. ${ }^{9,10}$

During this study, a C306A single nucleotide polymorphism (SNP) was found in 1/34 patients (frequency: $2 \cdot 9 \%$ ). It is a same sense mutation that does not change the corresponding amino acid residue (Pro 102). This base change is classified as a polymorphism as it was found in $1 / 42$ healthy $\mathrm{CEPH}^{11}$ Caucasian individuals (frequency: $2 \cdot 3 \%$ ) and 2/36 healthy Asian individuals (frequency: 5•4\%). It was not found in any of 33 healthy African-American individuals.

\footnotetext{
* Author to whom all correspondence should be addressed at: Laboratory of Immunobiology, National Cancer Institute at Frederick, Frederick, MD 21702-1201, USA. Tel: +1 301846 7328; Fax: +1 301846 6145; E-mail: andreazzolid@mail.ncifcrf.gov
} 
Table 1. Changes in the restriction pattern introduced by the C306A SNP

\begin{tabular}{lcl}
\hline Change & Position in the PCR product (bp) & \multicolumn{1}{c}{ Pattern } \\
\hline Abolished sites & & \\
Bcnl & 56 & Three bands $(10 \mathrm{bp}, 61 \mathrm{bp}, 82 \mathrm{bp})$ \\
Ncil & 56 & As above \\
BsiSI & 57 & Three bands $(9 \mathrm{bp}, 61 \mathrm{bp}, 83 \mathrm{bp})$ \\
Hapll & 57 & As above \\
Hin2I & 57 & As above \\
Hpall & 57 & As above \\
Mspl & 57 & As above \\
Created sites & & \\
Bst2UI & 56 & Three bands $(13 \mathrm{bp}, 43 \mathrm{bp}, 97 \mathrm{bp})$ \\
BstNI & 56 & As above \\
BstOI & 56 & As above \\
EcoRII & 56 & As above \\
& & \\
\end{tabular}

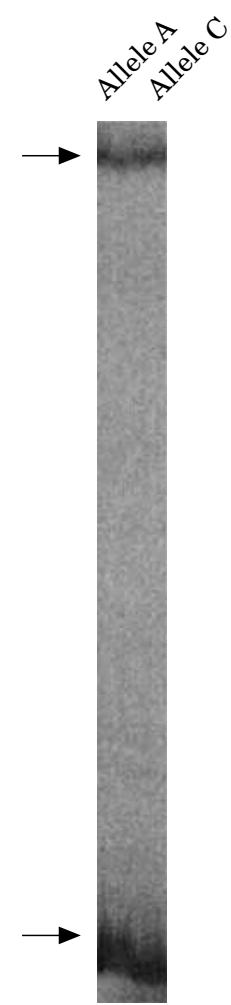

(a)

\section{TTCCCGG}

Allele C

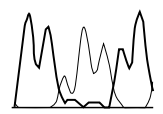

ITCCAGGC

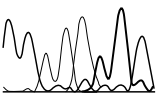

(b)

Fig. 1. SSCP mutation analysis of the CEBPD gene in lung cancer patients with the $2 \mathrm{BFw}-2 \mathrm{Rv}$ primers revealed the presence of the $\mathrm{C} 306 \mathrm{~A}$ SNP, present also in normal control individuals. (a) SSCP profile of allele ' $A$ ' and allele ' $\mathrm{C}$ '. (b) Corresponding sequence.

\section{MATERIALS AND METHODS}

\section{Primer sequences}

Two primers were used, with the following sequences: CEBP-2BFw, 5' TGG AGC TGT GCC ACG ACG AG3'; CEBP-2Rv, 5' AGT CGG GCT CGC GCT TGA GC3'.

\section{Polymerase chain reaction-single-strand conformational polymorphism (PCR-SSCP) analysis}

The radioactive reaction was performed in a total reaction volume of $12.5 \mu \mathrm{l}$, containing $100 \mathrm{ng}$ of genomic DNA, $12.5 \mathrm{pmol}$ of each primer, $200 \mu \mathrm{M}$ dNTPs, $1.5 \mathrm{mM}, \mathrm{MgCl}_{2}, 1.25 \mathrm{nCi} \alpha^{35} \mathrm{~S}$-dATP, $0.5 \mathrm{M}$ GC-RICH resolution buffer (GC-RICH PCR System, Roche Molecular Biochemicals, Indianapolis, IN, USA). Primers amplify a 153-bp product under the following cycling conditions: $3 \mathrm{~min}$ at $95^{\circ} \mathrm{C}(1 \mathrm{~min}$ at $95^{\circ} \mathrm{C}, 30 \mathrm{~s}$ at $64^{\circ} \mathrm{C}, 1 \mathrm{~min}$ at $72^{\circ} \mathrm{C}$ ) for 35 cycles; $7 \mathrm{~min}$ extension at $72^{\circ} \mathrm{C}$. After heat denaturation $(8 \mathrm{~min}$ at $90^{\circ} \mathrm{C}$ ) in formamide buffer (Stop Solution, Amersham, Arlington Heights, IL, USA), PCR products (154 bp) were run overnight in a $0.5 \times$ Mutation Detection Enhancement (MDE) gel (FMC Bioproducts, Rockland, ME, USA), $0.6 \times$ Tris Borate EDTA buffer (TBE), at room temperature, $8 \mathrm{~W}$ constant power; transferred on 3MM paper, dried and exposed to autoradiography film (X-OMAT AR, Kodak, Rochester, NY, USA).

\section{Sequencing}

Sequencing reactions were done either manually (T7 Sequenase Kit, Amersham) or automatically (ABI 373 Stretch Automated DNA Sequencer, Applied Biosystems, Foster City, CA, USA).

\section{Restriction analysis}

The C306A SNP introduces the restriction pattern changes summarized in Table 1. They can be analysed on high-resolution gel, such as $4 \cdot 5-5 \%$ NuSieve GTG Agarose (FMC, Rockland, ME, USA). 


\section{RESULTS AND DISCUSSION}

\section{Frequency}

Forty-two Caucasian CEPH ${ }^{11}$ control individuals were analysed. One (1334-02) was found heterozygous for the allele 'A' (Fig. 1). The carrier family 1334 has been analysed for this polymorphism to prove Mendelian co-dominant inheritance of the genotypic trait (data not shown).

Two out of 36 Asian normal individuals were found heterozygous for the same SNP. None out of the 33 normal African-American individuals tested carries the polymorphism.

\section{ACKNOWLEDGEMENT}

This project has been funded in toto with funds from the National Cancer Institute, National Institutes of Health, under Contract No. NO1-CO-56000. The content of the publication does not necessarily reflect the views or policies of the Department of Health and Human Services, nor does mention of trade names, commercial products, or organizations imply endorsement by the US Government.

\section{REFERENCES}

1. Johnson, P. F. \& Williams, S. C. (1994). CCAAT/enhancer binding (C/EBP) proteins. In Liver Gene Expression (Tronche, F. \& Yaniv, M., eds). Pp. 231-58. Austin, TX: R. G. Landes.

2. Breed, D. R., Margraf, L. R., Alcorn, J. L. \& Mendelson, C. R. (1997). Transcription factor C/EBPdelta in fetal lung: developmental regulation and effects of cyclic adenosine $3^{\prime}, 5^{\prime}$-monophosphate and glucocorticoids. Endocrinology 138, 5527-34.

3. Li, F., Rosenberg, E., Smith, C. I. et al. (1995). Correlation of expression of transcription factor C/EBP alpha and surfactant protein genes in lung cells. American Journal of Physiology 269, L241-7.

4. Nord, M., Lag, M., Cassel, T. N. et al. (1998). Regulation of CCSP (PCB-BP/uteroglobin) expression in primary cultures of lung cells: involvement of C/EBP. DNA Cell Biology 17, 481-92.

5. Solito, E., de Coupade, C., Parente, L., Flower, R. I. \& Russo-Marie, F. (1998). IL-6 stimulates annexin 1 expression and translocation and suggests a new biological role as class II acute phase protein. Cytokine 10, 514-21.

6. Sugahara, K., Sadohara, T., Sugita, M., Iyama, K. \& Takiguchi, M. (1999). Differential expression of CCAAT enhancer binding protein family in rat alveolar epithelial cell proliferation and in acute lung injury. Cell Tissue Research 297, 261-70.

7. Cassel, T. N., Nordlund-Moller, L., Andersson, O., Gustafsson, J. A. \& Nord, M. (2000). C/EBPalpha and C/EBPdelta activate the clara cell secretory protein gene through interaction with two adjacent C/EBPbinding sites. American Journal of Respiratory Cell Molecular Biology 22, 469-80.

8. Malkinson, A. M. (1998). Molecular comparison of human and mouse pulmonary adenocarcinomas. Experimental Lung Research 24, 541-55.

9. Johnson, B. E., Makuch, R. W., Simmons, A. D., Gazdar, A. F., Burch, D. \& Cashell, A.W. (1988). myc family DNA amplification in small cell lung cancer patients' tumors and corresponding cell lines. Cancer Research 48, 5163-6.

10. Phelps, R. M., Johnson, B. E., Ihde, D. C. et al. (1996). $\mathrm{NCl}-\mathrm{Navy}$ Medical Oncology Branch cell line data base. Journal of Cellular Biochemistry Supplement 24, 32-91.

11. Dausset, J., Cann, H., Cohen, D., Lathrop, M., Lalouel, J.M. \& White, R. (1990). Centre d'étude du polymorphisme humain $(\mathrm{CEPH})$ : collaborative genetic mapping of the human genome. Genomics 6, 575-7. 